\title{
Potential pathogenic properties of members of the "Streptococcus milleri" group in relation to the production of endocarditis and abscesses
}

\author{
M. D. P. WILLCOX
}

Institute of Dental Research, 2 Chalmers Street, Surrey Hills, NSW 2010 and the Cooperative Research Centre for Eye Research and Technology, University of New South Wales, Sydney, NSW 2052, Australia

\begin{abstract}
Summary. The "Streptococcus milleri" (SMG) group have been shown to possess factors in vitro that may be involved in pathogenesis. All SMG strains are able to bind fibronectin via a cell-surface protein; the binding ranged from 12 to $198 \mathrm{~mol} / \mathrm{cell}$. Strains also bound to platelet-fibrin or fibrin clots and fibrinogen, giving maximum adhesion values of $16.5 \%$, $21.8 \%$ and $151 \mathrm{~mol} / \mathrm{cell}$ respectively. Members of the species $S$. constellatus produced thrombin-like activity. Lancefield group C SMG aggregated rat platelets, a bacterial cellsurface protein acting as mediator in the reaction. Most of the in-vitro factors did not correlate with each other, an indication that SMG strains possess a wide variety of pathogenic properties that may be involved in the production of abscesses or endocarditis. However, there was a correlation between the binding of large amounts of fibrinogen ( $>100 \mathrm{~mol} / \mathrm{cell}$ ) and the ability to aggregate platelets. This suggests that fibrinogen binding may aid in platelet aggregation.
\end{abstract}

\section{Introduction}

The "Streptococcus milleri" group (SMG) consists of three species-S. anginosus, S. intermedius and $S$. constellatus. ${ }^{1-3}$ Members of the SMG produce purulent abscesses in many areas of the body including the mouth, brain and spleen..$^{4-6}$ They account for $9-15 \%$ of all community-acquired endocarditis ${ }^{5}$ and have been shown to produce caries in gnotobiotic rats. Although able to cause severe disease, SMG strains constitute part of the normal flora of the human oral cavity, upper respiratory and gastrointestinal tracts. $^{5,6,8,9}$ The three species may be associated with different diseases within the body; for example $S$. intermedius strains are more likely to be isolated from dental plaque than other species, and strains causing urogenital infections or dental periapical abscesses are usually $S$. anginosus. ${ }^{2,3}$

SMG strains isolated from abscesses adhere in greater numbers to buccal epithelial cells and strains isolated from infections in the body, including abscesses, are able to bind more fibronectin than other strains. ${ }^{10}$ The amount of fibronectin bound by strains is related to their ability to adhere to saliva-coated hydroxyapatite. ${ }^{10}$ Furthermore, strains can produce enzymes that may hydrolyse connective tissue components. ${ }^{2}$ Recent data have demonstrated that strains possessing Lancefield group $\mathrm{C}$ polysaccharides are able to bind large amounts of albumin ${ }^{11}$ and this may be related to their ability to aggregate human platelets. $^{12}$

There are several stages in the development of endocarditis, the first stage of which is damage to the surface endothelium. This damaged surface accumulates platelets, fibrin, fibrinogen and fibronectin and forms vegetations that act as foci for infection. Bacteria that enter the blood stream then bind to the platelet-fibrin aggregates and further deposition of platelets and fibrin occurs. Eventually, the bacterialplatelet-fibrin aggregates become so large that they restrict the normal functioning of the heart valves. Bacterial products may also contribute to heart-valve destruction. The production of abscesses may follow a similar course, with bacterial adherent to epithelial or endothelial cells the first step, then deposition of platelets and fibrin. ${ }^{13}$

The aim of the present study was to examine strains for properties in vitro that may relate to their ability to produce endocarditis or abscesses in vivo. 


\section{Materials and methods}

\section{Bacterial strains}

Strains chosen belonged to each of the three SMG species; certain strains within each species crossreacted with antisera to Lancefield polysaccharides. The site of isolation of strains is given in table $\mathrm{I}$. Strains were grown in Brain-Heart Infusion Broth (BHI; Oxoid Ltd, Sydney, Australia), for $18 \mathrm{~h}$ at $37^{\circ} \mathrm{C}$, washed three times in phosphate-buffered saline (PBS) $\left(\mathrm{NaCl} \quad 8 \mathrm{~g} / \mathrm{L} \quad \mathrm{KCl} \mathrm{0.2} \mathrm{g} / \mathrm{L}, \quad \mathrm{Na}_{2} \mathrm{HPO}_{4} \quad 1.15 \mathrm{~g} / \mathrm{L}\right.$, $\mathrm{KH}_{2} \mathrm{PO}_{4} 0.2 \mathrm{~g} / \mathrm{l}$ ) and finally resuspended in PBS to an $\mathrm{OD}_{660}$ value of 1.0 (unless otherwise indicated).

\section{Binding to rat fibronectin and fibrinogen}

The assay used to measure the ability of strains to bind $1 \mu \mathrm{g}$ of fibronectin ( $\mathrm{Fn}$ ) has been described previously. ${ }^{10}{ }^{125}$ I-labelled $\mathrm{Fn}$ was allowed to bind to washed cell suspensions $\left(5 \times 10^{8}\right.$ cells, suspended in PBS containing bovine serum albumin $1 \% \mathrm{w} / \mathrm{v}$ and
Tween $200.05 \% \mathrm{v} / \mathrm{v}$ ) for $30 \mathrm{~min}$ at $37^{\circ} \mathrm{C}$. The cells were then centrifuged and the amount of radioactivity associated with the cell pellet was measured. Cells were also tested for fibronectin binding after digestion of the cell surface with the protease, $(1 \mathrm{mg} / \mathrm{ml}$; Sigma) for $1 \mathrm{~h}$ at $37^{\circ} \mathrm{C}$, with subsequent extensive washing in buffer to remove the enzyme. Certain strains were examined for their ability to bind ${ }^{125}$ I-labelled rat fibrinogen. The method was as described above, but with the substitution of $1 \mu \mathrm{g}$ of ${ }^{125} \mathrm{I}$-fibrinogen for the fibronectin.

\section{Hydrophobicity}

A standard method ${ }^{14}$ was used to measure the relative hydrophobicities of the strains. Washed cells $(3.0 \mathrm{ml})$ were mixed for $60 \mathrm{~s}$ with $200 \mu \mathrm{l}$ of hexadecane. The percentage hydrophobicity was measured as the decrease in optical density of the aqueous phase compared to controls with no hexadecane added. The effect of bound fibronectin on bacterial cell-surface hydrophobicity was determined after allowing cells to

Table 1. Site of isolation and disease association of strains of SMG

\begin{tabular}{|c|c|c|c|c|}
\hline Species & Strain & $\begin{array}{c}\text { Lancefield } \\
\text { group }{ }^{*}\end{array}$ & $\begin{array}{l}\text { Isolation } \\
\text { site }\end{array}$ & Associated disease \\
\hline \multirow[t]{6}{*}{ S. anginosus } & POW 1 & $\mathrm{C}$ & Appendix & Abscess \\
\hline & C.117221-1 & $\mathrm{C}$ & Perirectal & Abscess \\
\hline & $\mathrm{F} 4$ & $F$ & Sputum & Chest infection \\
\hline & NHM 10 & A & Perinephric swab & Nephritis \\
\hline & G5:3 & - & Dental plaque & Normal oral flora \\
\hline & PC 4390 & $\mathrm{C}$ & Dental plaque & Normal oral flora \\
\hline \multirow[t]{4}{*}{ S. constellatus } & POW 5 & $\mathrm{~F}$ & Blood & Endocarditis \\
\hline & AM 699 & - & Dental plaque & Normal oral flora \\
\hline & NCTC 10714 & $\mathbf{F}$ & Throat & Normal pharyngeal flora \\
\hline & NCTC 11063 & - & Throat & Normal pharyngeal flora \\
\hline \multirow{3}{*}{ S. intermedius } & $\mathrm{C} 5$ & $\mathrm{C}$ & Throat & Pharyngitis \\
\hline & UNS 35 & - & Brain & Abscess \\
\hline & POW 3 & - & Brain & Abscess \\
\hline
\end{tabular}

${ }^{*}$ Lancefield group determined by use of commercially available test kit (Oxoid Ltd, Sydney, Australia).

Table II. Binding of fibronectin to SMG strains and the effect on cell-surface hydrophobicity

\begin{tabular}{llccc}
\hline Species & Strain & $\begin{array}{c}\text { Fibronectin } \\
\text { (binding } \\
\text { (mol/cell) }\end{array}$ & $\begin{array}{c}\text { Effect of } \\
\text { protease } \\
\text { on fibronectin } \\
\text { binding (\% } \\
\text { decrease) }\end{array}$ & $\begin{array}{c}\text { Change in } \\
\text { cell-surface } \\
\text { hydrophobicity } \\
\text { (\% increase) }\end{array}$ \\
\hline S. anginosus & POW 1 & 96 & 94 & 7 \\
& C117221-1 & 74 & 88 & 4 \\
& F4 & 198 & 97 & 36 \\
& NHM 10 & 12 & 92 & 3 \\
& G5:3 & 24 & 92 & 43 \\
S. constellatus & PC 4890 & 70 & 93 & 14 \\
& POW 5 & 31 & 45 & 9 \\
& AM 699 & 25 & 80 & 91 \\
& NCTC 10714 & 23 & 70 & 5 \\
& NCTC 11063 & 62 & 81 & 5 \\
& C5 & 105 & 97 & 29 \\
& UNS 35 & 56 & 93 & 91 \\
& POW 3 & 57 & 81 & \\
\end{tabular}

All standard deviations were $<10 \%$ of the mean. 
bind fibronectin (see above). Cells were washed three times in PBS to remove unbound fibronectin and resuspended in the original volume of PBS.

\section{Production of thrombin-like activity}

Thrombin-like activity was measured with the fluorescent substrate $N$-tert-butoxycarbonyl (BOC)Val-Pro-Arg-7-Amido-4-methylcoumarin (AMC, a synthetic substrate for thrombin-like activity; Sigma). The substrate was dissolved in a minimum of dimethylsulphoxide and diluted in $50 \mathrm{~mm} N$-Tris (hydroxymethyl) methyl-2-aminoethenesulphonic acid buffer, $\mathrm{pH} 7.5$ (TES) to $100 \mu \mathrm{g} / \mathrm{ml}$. A suspension of whole bacterial cells suspended in TES to an $\mathrm{OD}_{620}$ of $0 \cdot 1$ $(50 \mu \mathrm{l})$ was mixed with $20 \mu \mathrm{l}$ of substrate and incubated for $24 \mathrm{~h}$ at $37^{\circ} \mathrm{C}$. Substrate degradation was visualised by measuring the release of the fluorogenic compound under uv illumination.

\section{Adhesion of strains to platelet-fibrin or fibrin clots}

Rat platelet-fibrin clots were made by the addition of $\mathrm{CaCl}_{2}\left(0.1 \mathrm{M}\right.$ final concentration) to $7.5 \times 10^{7}$ platelets in plasma in a 96-well microtitration plate. Blood was obtained from rats by exsanguination of the heart under anaesthesia. Fresh blood was mixed immediately with $0 \cdot 1 \mathrm{M}$ trisodium citrate $(9: 1 \mathrm{vol}: \mathrm{vol})$ and centrifuged at $100 \mathrm{~g}$ for $20 \mathrm{~min}$ at $20^{\circ} \mathrm{C}$. The supernatant platelet-rich plasma (PRP) was removed and the remaining blood was centrifuged at $3000 \mathrm{~g}$ for $10 \mathrm{~min}$ to give platelet-poor plasma (PPP). Fibrin clots were made by adding $100 \mu \mathrm{l}$ of PPP and $50 \mu \mathrm{l}$ of $\mathrm{CaCl}_{2}$ (final concentration of $0.1 \mathrm{M}$ ) to wells in a 96 well microtitration plate. The clots were allowed to form at $37^{\circ} \mathrm{C}$ for $2 \mathrm{~h}$ and $4^{\circ} \mathrm{C}$ for $18 \mathrm{~h}$. Clots were then washed with PBST, three times.

The bacteria were grown for $18 \mathrm{~h}$ in BHI containing yeast extract $0.5 \% \mathrm{w} / \mathrm{v}$ in the presence of ${ }^{3} \mathrm{H}$ thymidine $2 \mu \mathrm{Ci} / \mathrm{ml}$. Cells were washed in PBS containing Tween $200.05 \% \mathrm{v} / \mathrm{v}$ and bacterial cells $(100 \mu \mathrm{l}$, $\mathrm{OD}_{660} 0 \cdot 1$ ), suspended in PBST, were added to individual clots. The bacteria and clots were incubated for $1 \mathrm{~h}$ at ambient temperature. Subsequent extensive washing (three times) in PBST removed the nonadherent cells. The clots were then removed from the wells and added to scintillin prior to $\beta$-counting. The amount of binding was expressed as a percentage of the radioactivity compared with $100 \mu$ l of bacterial cell suspension.

\section{Aggregation of rat platelets}

Six strains were selected to be tested for their aggregation of platelets on the basis of differences seen in thrombin-like activity, fibronectin binding and adhesion to clots. Washed bacteria were concentrated four-fold, giving a standard suspension of $4 \times 10^{9}$ cells $/ \mathrm{ml}$. Blood was obtained from rats by exsanguination of the heart under anaesthesia. Fresh blood was mixed immediately with $0.1 \mathrm{M}$ trisodium citrate (9:1 vol:vol) and centrifuged at $100 \mathrm{~g}$ for $20 \mathrm{~min}$ at $20^{\circ} \mathrm{C}$. The supernate (PRP) was removed and the remaining blood centrifuged at $3000 \mathrm{~g}$ for 10 min to give PPP. PRP was adjusted with PPP to give an $\mathrm{OD}_{600}$ of 0.5 . A standard reaction mixture of $0.25 \mathrm{ml}$ of fresh PRP and $0.25 \mathrm{ml}$ of bacterial suspension was tested at $37^{\circ} \mathrm{C}$ with controlled stirring on a recording aggregometer (Chrono-log Corp.). After a baseline was established with PRP, the bacterial suspension was added to the cuvette. ADP was added to PRP suspensions as a positive control for normal platelet aggregation and also after incubation of bacteria and platelet for $22 \mathrm{~min}$ to test the degree of aggregation seen. Strains were also tested for plateletaggregating ability after protease treatment of the cell surface (see above).

\section{Statistical analysis}

Statistical differences between data sets were evaluated by the package SPSS and analysed by the Mann-Whitney U-test.

\section{Results}

Binding of fibronectin to strains and the effect on cellsurface hydrophobicity

Table II demonstrates the ability of strains to bind to rat fibronectin. Strains within each species showed a wide variation. $S$. anginosus $\mathrm{F} 4$ produced the greatest level of binding, $10 \%$ of total added fibronectin whereas S.anginosus NHM 10 bound only $1 \%$. Protease treatment of the cell surface resulted in significant reductions in fibronectin binding. Most strains showed $>80 \%$ reduction in binding and all showed $\geqslant 45 \%$ reduction after protease treatment (table II).

The cell-surface hydrophobicity of all strains was increased by 3-36\% after binding fibronectin. However, the amount of fibronectin binding did not correlate with the increase in hydrophobicity. For example. $S$. anginosus $\mathrm{F} 4$ bound the most fibronectin, $10 \% 1 \mu \mathrm{g}$, and gave a $36 \%$ increase in cell-surface hydrophobicity when fibronectin was bound to the cell surface, whereas $S$. intermedius $\mathrm{C} 5$ gave the second highest degree of binding to fibronectin $(8.5 \%)$, but with an increase of only $5 \%$ in the cell-surface hydrophobicity in the presence of fibronectin.

\section{Production of thrombin-like activity}

Only strains of $S$. constellatus produced thrombinlike activity. This was seen as blue fluorescence when cell suspensions were viewed under uv light.

\section{Adhesion of strains to platelet-fibrin or fibrin clots}

All strains were able to adhere to the platelet-fibrin or fibrin clots (table III). For platelet-fibrin clots, the 
Table III. Adhesion to platelet-fibrin and fibrin clots

\begin{tabular}{lccc}
\hline Strain & $\begin{array}{c}\text { Adhesion to } \\
\text { platelet-fibrin } \\
\text { clot }(\%)\end{array}$ & $\begin{array}{c}\text { Adhesion to } \\
\text { fibrin clot } \\
(\%)\end{array}$ & $\begin{array}{c}\text { Binding to } \\
\text { fibrinogen } \\
\text { (mol/cell) }\end{array}$ \\
\hline POW 1 & 7.2 & 21.8 & 103 \\
C117221-1 & 16.5 & 10.8 & 102 \\
F4 & 4.7 & 3.4 & 1 \\
NHM 10 & 1.6 & 10.9 & NT \\
G5:3 & 4.2 & 7.8 & NT \\
PC 4390 & 1.4 & 3.4 & NT \\
POW 5 & 2.7 & 5.3 & 24 \\
AM 699 & 2.3 & NT & NT \\
NCTC 10714 & 1.7 & NT & NT \\
NCTC 11063 & 1.7 & NT & NT \\
C5 & 1.4 & 3.4 & 151 \\
UNS 35 & 2.6 & NT & NT \\
POW 3 & NT & NT & 99 \\
& & & \\
\hline
\end{tabular}

Standard deviations were always $<20 \%$ of the mean.

NT, not tested.

adhesion ranged from $1.4 \%$ (strains $\mathrm{C} 5$ and $\mathrm{PC} 4390$ ) to $16.5 \%$ for strain $\mathrm{C} 117221-1$. On the other hand, for fibrin clots, strain POWl gave the highest adhesion $(21 \cdot 8 \%)$ and strain PC 4390 gave the lowest $(3 \cdot 4 \%)$.
Generally, strains adhered better to the fibrin clots than to platelet-fibrin clots. There was no correlation between fibronectin binding and adhesion to either clot type.

All the strains tested bound fibrinogen, with values ranging from $1 \mathrm{~mol} /$ cell to $151 \mathrm{~mol} /$ cell (table III). No correlation was evident between binding to fibrinogen and fibronectin binding, or adhesion to clots.

\section{Aggregation of rat platelets}

All strains tested showed some reaction when added to platelet-rich plasma (figure). After the addition of ADP at $22 \mathrm{~min}$, increased platelet aggregation was seen with strains POW 5, POW 3 and F4, that gave the lowest values. Protease treatment eliminated the platelet-bacterial interaction for all strains. A control of ADP, added after $22 \mathrm{~min}$, aggregated platelets, an indication that they were still in a functional state.

There was no correlation between the ability to aggregate platelets and the ability to adhere to plateletfibrin clots. Strain C5 aggregated platelets and yet gave a low level of adhesion to platelet-fibrin clots, whereas

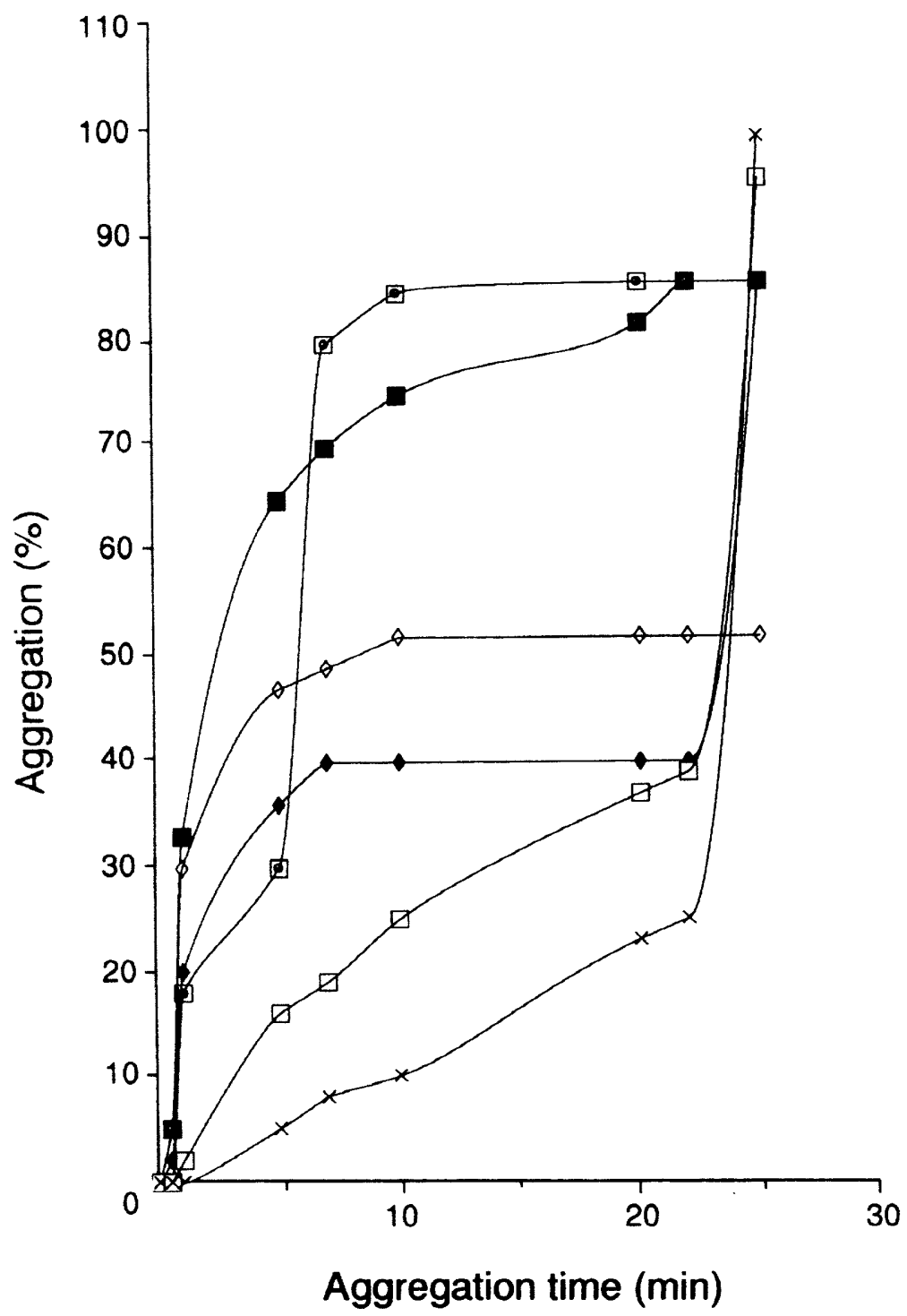

Figure. Aggregation of rat platelets by SMG POW $1 \oplus$; C5 $\square$, C117221-1 $\diamond$; F4 $\bullet$; POW $5 \square$, POW 3 X. 
strain C17221-1 aggregated platelets and gave a high degree of adhesion to platelet-fibrin clots. The three strains that showed the greatest adhesion to fibrinonogen ( $>100 \mathrm{~mol} / \mathrm{cell}$ ) could aggregate platelets completely. There was no relationship between species and ability to adhere to clots.

\section{Discussion}

This study has shown that SMG strains display a range of characteristics that may be important pathogenic determinants in the formation of both abscesses and endocarditis. Previous studies have demonstrated associations between certain types of SMG and diseases. For example, S. intermedius strains are commonly isolated from brain abscesses and hyaluronidase-producing strains are more commonly isolated from abscesses. ${ }^{15} \mathrm{~S}$. anginosus is more likely to be isolated from urogenital or dental abscesses, ${ }^{2,3}$ The present study did not find any significant differences among the three species with respect to protein binding or adhesion. S. constellatus was the only species able to produce thrombin-like activity, the Lancefield group $C$ strains were the only strains capable of aggregating platelets.

The ability to bind to fibronectin has been shown previously to be related to adhesion of SMG to salivacoated hydroxyapatite and the isolation of strains from infections. ${ }^{10}$ It is now clear that the binding of fibonectin is mediated by proteins on the cell surface and that fibronectin binding increases the cell-surface hydrophobicity of strains to varying degrees. The ability of Staphylococcus aureus strains to bind fibronectin is correlated with their ability to invade the body ${ }^{16}$ and fibronectin associated with fibrin clots promotes the adhesion of $S$. aureus to the clot. ${ }^{17}$ Mutants of $S$. aureus that showed a reduction in binding to fibronectin also showed reduced adhesion to rat heart values. ${ }^{18}$ For the viridans streptococci, it has been shown that inactivation of fibronectin binding by transposon mutagenesis results in a reduced virulence of strains in the rabbit model of endocarditis. ${ }^{19}$ Furthermore, for group C streptococci isolated from wounds, fibronectin or the C-terminal domain was critical for adhesion to fibrin clots. ${ }^{20}$ It has been demonstrated that bacteria coated with fibronectin are more easily phagoycytosed by polymorphonuclear leucocytes or macrophages. ${ }^{21,22}$ Thus the binding of fibronectin to bacteria may have a dual role, allowing the bacteria to adhere to surfaces and also in the promotion of ingestion of bacteria by host defence cells.

The ability of strains to adhere to clots may also be a pathogenic determinant, as the first step in the production of endocarditis is considered to be deposition of platelets and fibrin clots on the heart valve, followed by bacterial adhesion. Recent evidence has shown that $S$. sanguis strains that bind to plateletfibrin clots are more virulent in a rat model of endocarditis. ${ }^{23}$ In the present study, there was no direct relationship between fibronectin and clot binding. However, strains are able to bind to fibrinogen, and it may be that strains bind to platelet-fibrin clots by the use of a combination of fibrinogen and fibronectin-binding mechanisms as well as adhesion to fibrin or platelets.

The production of thrombin-like activity may indicate the possession of another biochemical characteristic that is correlated with disease. Thrombin converts fibrinogen to fibrin and is one of the major enzymes in the blood coagulation pathway. Coagulation of plasma may be a factor in the production of abscesses and endocarditis as a primary step in sealing off bacteria in a platelet-fibrin clot. This process is thought to be beneficial to the host, as the pathogens are contained in defined areas. However, recent evidence suggests that the production of bacterialplatelet-fibrin clots may also be beneficial to the bacteria. Phagocytes isolated from abscesses have been shown to be ineffective in killing bacteria, ${ }^{24}$ and, also, the production of platelet-fibrin clots around bacteria may effectively isolate them from other elements of the host defence system.

Platelet aggregation may be a prerequisite for the production and progression of abscesses or endocarditis. In a previous study, it was demonstrated that the SMG cross-reacting with Lancefield group C antisera were the only strains able to aggregate human platelets. ${ }^{12}$ The current study demonstrated that all strains reacted to some extent with rat platelets, but only strains of Lancefield group $\mathrm{C}$ showed complete aggregation as determined by the addition of ADP at $22 \mathrm{~min}$. The other strains either aggregated platelets incompletely or caused platelet agglutination only, as ADP increased the aggregation response. Thus, the SMG types that aggregate rat platelets are the same types that aggregate human platelets. The platelet aggregation response appeared to be due to a cellsurface protein on the SMG, as protease treatment of cells prevented aggregation. Platelet aggregation did not correlate with the ability of cells to bind fibronectin, or the production of thrombin-like activity, but there was a correlation between the ability to bind large amounts of fibrinogen $(>100 \mathrm{~mol} / \mathrm{cell})$ and platelet aggregation. Platelets are known to possess a fibrinogen receptor ${ }^{25}$ and the binding of fibrinogen to bacteria may be necessary for the subsequent adhesion to, or aggregation of, platelets.

In conclusion, the SMG possess several cell-surface characteristics that may be related to their ability to produce abscesses and endocarditis. Thrombin-like activity was demonstrated with a synthetic fluorescentlabelled substrate and was expressed by $S$. constellatus strains only. Only strains that cross-reacted with Lancefield group C antisera showed complete aggregation of rat platelets. All strains were able to bind rat fibronectin, the binding mediated by a cell-surface protein, and all strains tested were able to adhere to platelet-fibrin or fibrin clots. Fibrinogen binding may 
be a prerequisite for platelet aggregation, as strains binding large amounts of fibrinogen aggregated platelets.

\section{References}

1. Whiley RA, Hardie JM. DNA-DNA hybridization studies and phenotypic characteristics of strains within the 'Streptococcus milleri group'. J Gen Microbiol 1989; 135: 2623-2633.

2. Whiley RA, Fraser H, Hardie JM, Beighton D. Phenotypic differentiation of Streptococcus intermedius, Streptococcus constellatus, and Streptococcus anginosus strains within the "Streptococcus milleri group". J Clin Microbiol 1990; 28 : 1497-1501.

3. Whiley RA, Beighton D. Emended descriptions and recognition of Streptococcus constellatus, Streptococcus intermedius, and Streptococcus anginosus as distinct species. Int J Syst Bacteriol $1991 ; 41: 1-5$.

4. Fisher LE, Russell RRB. The isolation and characterization of milleri group streptococci from dental periapical abscesses. $J$ Dent Res 1993; 72: 1191-1193.

5. Gossling J. Occurrence and pathogenicity of the Streptococcus milleri group. Rev Infect Dis 1988; 10: 257-285.

6. Ruoff KL. Streptococcus anginosus ("Streptococcus milleri'): the unrecognized pathogen. Clin Microbiol Rev 1988; 1 : $102-108$.

7. Drucker, DB, Green RM. The relative cariogenicities of Streptococcus milleri and other viridans group streptococci in gnotobiotic hooded rats. Arch Oral Biol 1978; 23: 183-187.

8. Mejàré B, Edwardsson S. Streptococcus milleri (Guthof); an indigenous organism of the human oral cavity. Arch Oral Biol 1975; 20 : 757-762.

9. Piscitelli SC, Shwed J, Schreckenberger P, Danziger LH. Streptococcus milleri group: renewed interest in an elusive pathogen. Eur J Clin Microbiol Infect Dis 1992; 11: 491-498

10. Willcox MDP, Knox KW. Surface-associated properties of Streptococcus milleri group strains and their potential relation to pathogenesis. J Med Microbiol 1990; 31: 259-270.

11. Willcox MDP, Patrikakis M, Loo CY, Knox KW. Albuminbinding proteins on the surface of the Streptococcus milleri group and characterization of the albumin receptor of Streptococcus intermedius C5. J Gen Microbiol 1993; 139 . $2451-2458$.

12. Willcox MDP, Oakey HJ, Harty DWS, Patrikakis M, Knox $\mathrm{KW}$. Lancefield group C Streptococcus milleri group strains aggregate human platelets. Microb Pathog 1994; 16 : $451-457$.
This work was supported by grants from the National Health and Medical Research Council of Australia and the Australian Dental Research Fund Inc. Dr R. A. Whiley supplied many of the strains used in this study.

13. Rotstein OD. Role of fibrin deposition in the pathogenesis of intraabdominal infection. Eur J Clin Microbiol Infect Dis 1992; 11: 1064-1068.

14. Rosenberg M, Gutnick D, Rosenberg E. Adherence of bacteria to hydrocarbons: a simple method for measuring cellsurface hydrophobicity. FEMS Microbiol Lett 1980; 9: 29-33.

15. Unsworth PF. Hyaluronidase production in Streptococcus milleri in relation to infection. J Clin Pathol 1989; 42: 506-510.

16. Proctor RA, Christman, G, Mosher DF. Fibronectin-induced agglutination of Staphlococcus aureus correlates with invasiveness. $J$ Lab Clin Med 1984; 104: 455-459.

17. Toy PTCY, Lai L-W, Drake TA, Sande MA. Effect of fibronectin on adherence of Staphylococcus aureus to fibrin thrombi in vitro. Infect Immun 1985; 48: 83-86.

18. Kuypers JM, Proctor RA. Reduced adherence to traumatized rat heart valves by a low-fibronectin-binding mutant of Staphylococcus aureus. Infect Immun 1989; 57: 2306-2312.

19. Lowrance JH, Baddour LM, Simpson WA. The role of fibronectin binding in the rat model of experimental endocarditis caused by Streptococcus sanguis. J Clin Invest 1990; 86: 7-13.

20. Chhatwal GS, Valentin-Weigand P, Timmis KN. Bacterial infection of wounds: fibronectin-mediated adherence of group $\mathrm{A}$ and $\mathrm{C}$ streptococci to fibrin thrombi in vitro. Infect Immun 1990; 58: 3015-3019.

21. Yang KD, Augustine NH, Gonzalez LA, Bohnsack JF, Hill HR. Effects of fibronectin on the interaction of polymorphonuclear leukocytes with unopsonized and antibody-opsonized bacteria. $J$ Infect Dis 1988; 158: 823-830.

22. Kluftinger JL, Kelly, NM, Jost BH, Hancock REW. Fibronectin as an enhancer of nonopsonic phagocytosis of Pseudomonas aeruginosa by macrophages. Infect Immun $1989 ; 57: 2782-2785$.

23. Manning JE, Hume EBH, Hunter N, Knox KW. An appraisal of the virulence factors associated with streptococcal endocarditis. J Med Microbiol 1994; 40: 110-114.

24. Finlay-Jones JJ, Hart PH, Spencer LK, Nulsen MF, Kenny PA, McDonald PJ. Bacterial killing in vitro by abscess-derived neutrophils. J Med Microbiol 1991; 34: 73-81.

25. Gartner TK, Bennett JS. The tetrapeptide analogue of the cell attachment site of fibronectin inhibits platelet aggregation and fibrinogen binding to activated platelets. $J$ Biol Chem 1985; 260: 11891-11894. 